\title{
Innopolis University and Innopolis Lyceum: Education Area of Innopolis City - the New IT Capital of Russia
}

\author{
Nadezda A. SULIMOVA ${ }^{1}$, Marina S. TSVETKOVA ${ }^{2}$ \\ ${ }^{1}$ Lyceum Innopolis \\ 1, Kvantovy boulevard, Innopolis, 420500, Russian Federation \\ Academy of Improvement of Professional Skill and Professional Retraining of Educators \\ 8 Golovinskoe Shosse, Moscow 125212, Russian Federation \\ e-mail:nadezhda.sulimova@gmail.com,ms-tsv@mail.ru
}

\begin{abstract}
Mission of Innopolis project is to create favourable opportunities for the economic growth of the Russian Federation through further development of Information Technology, improving the welfare of the nation and creation of a highly professional and intellectual society.
\end{abstract}

Keywords: Informatics, computer science, curriculum in IT universities.

\section{Introduction}

Innopolis is an IT city (Fig. 1), the first Russian university focusing on advanced Computer Science:

- Prospective population of 150 thousand people, 60 thousand of them are to be represented by highly-skilled professionals.

- Territory of more than 1,200 Ha.

- A special economic zone of technology development type and technology parks offering preferences for investors and residents.

- Comfortable and affordable housing, modern educational, medical, sports and entertainment infrastructure - implementation of the "Live, learn, work and play" concept.

- Picturesque, ecologically clean area.

The project was launched in July, 2012.

The first construction stage of Innopolis city is to be completed by August, 2015 (infrastructure for life and work of 5 thousand people). 


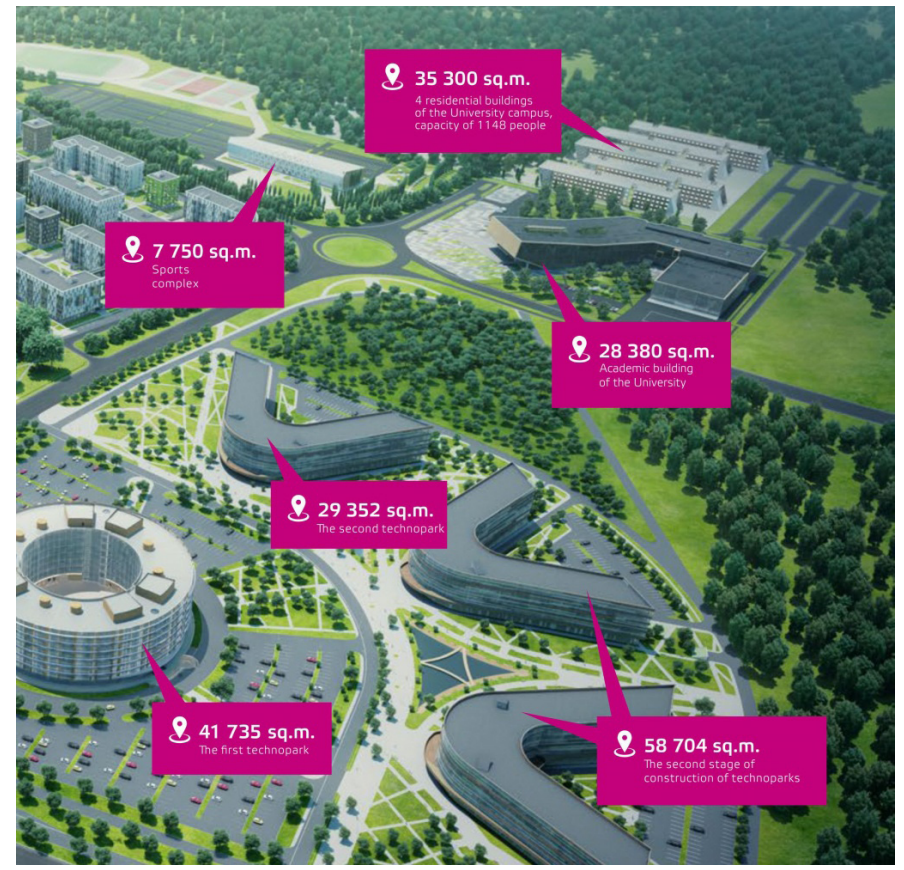

Fig. 1. Plan of Innopolis city.

\section{Innopolis University: Innovative IT Education}

Innopolis University (IU, 2016) is a new Russian university that focuses on research and educational activities in the field of Computer Science, is an intellectual driving force in the development of the national IT industry.

Its Bachelor, Master, and post-graduate programs are aimed at producing future specialists in cutting-edge technologies. The university also offers pre-university preparation classes and courses to enhance the competencies of experts employed in IT companies.

Functions of Innopolis University:

- Training and professional development of highly qualified IT specialists based on innovative undergraduate, graduate, and non-degree programs in accordance with international principles and requirements established in the modern IT industry.

- Conducting breakthrough fundamental and applied research in the field of Information Technology as well as development of interdisciplinary research projects.

- Creating an academic atmosphere that attracts talented engineers, entrepreneurs, investors, young specialists, students, and schoolchildren.

- Providing favourable conditions for educational, research and technology-related activities, as well as promote entrepreneurship and innovation by forming clear mechanisms of research commercialization and ensuring easy access to the appropriate infrastructure which includes premium accommodation, light, spacious 
offices, modern equipment, the ecosystem for development and acceleration of start-up projects, and the attraction of venture capital investment.

- Intellectual enrichment of Innopolis city.

Study programs. Nowadays employers look for young and proactive specialists, on the one hand, and require from them broad practical experience and minimal adjustment to the internal processes in the company, on the other hand. In order to prepare students for a future job and develop their practical skills, Innopolis's study programs include more than $40 \%$ of practice in the form of team projects in every discipline. Within a final project designed for an external company, a team of students develops a programming solution from scratch through all stages: from collecting and analysing the requirements for testing a final version and submitting it to the client. This way students apply their theoretical knowledge in practice.

Bachelor's degree program. Innopolis University Bachelor's degree program, developed by the world's leading professors and IT experts, is designed to give students solid knowledge in IT. Bachelor program will provide graduates with key professional competencies required by the IT industry. The curriculum has been developed in close collaboration with top IT companies. Students will enjoy comfortable living conditions and effective educational environment in a new Russian city of Innopolis.

There are two options: 4-year program (full undergraduate program) and intensive two-year program ( $3^{\text {rd }}$ and $4^{\text {th }}$ years of studies).

Innopolis University offers the following four Master's programs - see Table 1.

Master programs. Master degrees of Innopolis University offer a high-quality IT education for young specialists and development engineers in the following programs: Software Engineering, Cyber Security, Data Sciences, and Robotics. The curriculums were designed in close collaboration with leading world partner universities. The program is available at the central location in Innopolis University, as well as in partner universities in the USA, Europe, and Asia.

Table 1

Master's programs

\begin{tabular}{lll}
\hline Program & Description & Duration \\
\hline Software Engineering (MSIT-SE) & Practical learning of all stages of software development & 1 year \\
Robotics & Industrial and scientific robotics & 2 years \\
Secure Systems and Network & $\begin{array}{l}\text { Acquiring the methods and means of keeping the data cohe- } \\
\text { rent, confidential and accessible in information systems. }\end{array}$ & 1 years \\
Engineering & $\begin{array}{l}\text { Learning the methods and instruments of preserving the data } \\
\text { and respecting access rights to the data in computer networks. }\end{array}$ & \\
& $\begin{array}{l}\text { Definition of problems with presented data, designing appro- } \\
\text { priate models and evaluation of validity of a model. Presenting } \\
\text { Big Data }\end{array}$ & 2 years \\
& $\begin{array}{l}\text { data in meaningful ways, testing for relationships within data, } \\
\text { testing hypothesis, and carrying out modeling techniques. }\end{array}$ \\
\hline
\end{tabular}




\section{IT Curriculum}

Nowadays employers look for young and proactive specialists, on the one hand, and require from them broad practical experience and minimal adjustment to the internal processes in the company, on the other hand. In order to prepare students for a future job and develop their practical skills, Innopolis's study programs include more than $40 \%$ of practice in the form of team projects in every discipline. Within a final project designed for an external company, a team of students develops a programming solution from scratch through all stages: from collecting and analysing the requirements for testing a final version and submitting it to the client. This way students apply their theoretical knowledge in practice.

In 2015/2016 Innopolis University offers the following 4 Master programs - see Table 2.

The curriculum consists of three parts:

Core courses. The curriculum is comprised of compulsory subjects necessary for professional development of engineers (Requirements, Architecture, Management, QA, PSP, Communications):

- Introduction to Personal Software Process.

- Models of Software Systems.

- Methods: Deciding What to Design.

- Managing Software Development.

- Analysis of Software Artefacts.

- Architectures for Software Systems.

- Communication for Software Engineers.

Table 2

2015/2016 Innopolis University’s Master programs

\begin{tabular}{|c|c|c|c|}
\hline Program & Desciption & Duration & Location \\
\hline Software Engineering & $\begin{array}{l}\text { Practical learning of all stages of software deve- } \\
\text { lopment (applying methods of Carnegie Mellon } \\
\text { University) }\end{array}$ & 1 year & Innopolis \\
\hline $\begin{array}{l}\text { Software Engineering } \\
\text { (introduction) }\end{array}$ & $\begin{array}{l}\text { This course connects the curriculum of Russian } \\
\text { technical universities and Software Engineering } \\
\text { program }\end{array}$ & 1 year & Amsterdam \\
\hline Robotics & Industrial and scientific robotics & 2 years & $\begin{array}{l}\text { 1st year - Innopolis, } \\
2 \text { d year - partner } \\
\text { university }\end{array}$ \\
\hline Information Security & $\begin{array}{l}\text { Acquiring the methods and means of keeping } \\
\text { the data coherent, confidential and accessible in } \\
\text { information systems }\end{array}$ & 2 years & $\begin{array}{l}\text { 1st year - Singapore } \\
2 \text { d year - Innopolis }\end{array}$ \\
\hline Network Security & $\begin{array}{l}\text { Learning the methods and instruments of preserving } \\
\text { the data and respecting access rights to the data in } \\
\text { computer networks. }\end{array}$ & 2 years & $\begin{array}{l}\text { 1st year - Amsterdam } \\
2 \text { d year - Innopolis }\end{array}$ \\
\hline
\end{tabular}


Elective courses. Students are given a choice of several electives, such as robotics, cloud systems, artificial intellect, and etc.

- Dynamical Software Testing.

- Introduction to Robotics.

- Advanced Topics in Software Engineering.

- Enterprise Systems.

- Affective Computations.

- Advanced Data Bases.

- Total Virtualization.

- Operating Systems.

- Basics of Information Security.

- Computer Vision.

- Cloud Systems.

Team project. Under guidance of experienced mentors, the students in teams of 3-5 will develop on their own an engineering project for an external client.

\section{Pre-Master's Program}

The aim of the program: To fulfil the gap in technical knowledge (OO concepts, programming in Java, algorithms, databases and English) and development experience and skills.

Intended audience: Incoming students that did not pass the admission process due to the lack of technical knowledge and/or industry experience. Length of the program: 1 year/2 semesters (Table 3 ).

Courses.

Practicum: 12 hours/week, 6 hours Labs with TA support.

Practicum: Students will be assigned to one of the OpenSource projects and contribute the code to the community. Alternatively, small industry projects might be assigned to the students.

After successful completion the students will continue their study as MSIT-SE students or select one of the academic master programs (BigData, Information security or Robotics).

Table 3

Length of the program: 1 year/2 semesters

\begin{tabular}{llllll}
\hline Sem I & $\begin{array}{l}\text { Object-oriented } \\
\text { Programing }\end{array}$ & $\begin{array}{l}\text { Data Structures and } \\
\text { Algorithms }\end{array}$ & $\begin{array}{l}\text { Data Modeling and } \\
\text { Databases }\end{array}$ & Philosophy & $\begin{array}{l}\text { English } \\
\text { Language I }\end{array}$ \\
\hline Sem II & $\begin{array}{l}\text { Software } \\
\text { Architecture }\end{array}$ & $\begin{array}{l}\text { Operating Systems } \\
\text { and Networks }\end{array}$ & Discrete Math/Logic & $\begin{array}{l}\text { Practicum I } \\
\text { (Java development } \\
\text { project) }\end{array}$ & $\begin{array}{l}\text { English } \\
\text { Language II }\end{array}$ \\
\hline
\end{tabular}




\section{Innopolis Lyceum}

In January 2016, educational institution for gifted students in Mathematics and Information Technology field started functioning in Innopolis city - State General Educational Institution “Lyceum Innopolis".Lyceum's mission is creating favorable conditions for the students' full intellectual development, taking their individual characteristics and abilities into account, the formation of a future profession conscious choice and civic education. Due to the fact that all the students who have successfully passed the tests are taken to the study, whatever remote regions of the Russian Federation they live in, the boarding school is organized at Lyceum. Education, accommodation in boarding school and five meals for all students is at the public funds expense (RFG, 2014; RFP, 2010).

The Lyceum Educational program focuses on training and education of talented children who have shown outstanding ability in the field of physical and mathematical disciplines. The main objective of the program is the development of individual, creative and research abilities of students in active learning and the use of computer science and information - communication technologies. Students 7-11 grades are taught in the Lyceum in groups of 15 people It is necessary to pass the competitive tests in Mathematics and Russian language, as well as English or Tatar languages of choice for entering the Lyceum. Additionally, each applicant for studying in Lyceum provides a portfolio of individual achievements in the field of Informatics and IT, Mathematics and Physics. The peculiarity of the Lyceum is the implementation of information technology profile and convergent approach to study subjects. And this creates a maximum-variation educational environment, taking individual characteristics and needs of each student's personality into account. Residential accommodation for students allows complete immersion into studying subjects. Each of the Lyceum students has at least two additional classes after compulsory lessons per day. Mandatory courses, among them are IT sphere according to one of the directions depending on the needs and interests of students and communicative skills development (English with native speakers, as well as Chinese and German languages). For the realization of profile directions classes on the additional chapters of Mathematics and Physics are provided.

Particular attention is paid to the Olimpiads preparation, competitions and contests, research and project work. Despite the short period of functioning of the Lyceum, school Olympiads were held on all subjects to determine the abilities, skill levels and interests of each student. Over a third of Lyceum students have participated in national competitions, inter-regional competitions of the Kazan Federal University, open competitions and contests of Innopolis University. Presentation and protection of research and design works of students will be held in April, as part of the «Days of Science» in Lyceum.

The most important component and key to the success of the Lyceum is part of a highly qualified teaching staff. There are winners of the regional and the final stages of the national competition «Teacher of the year», the owners of the Ministry of Education and Science of the Republic of Tatarstan grants, the winners of the priority national "Education" project, active participants in the professional teaching community among them. 
Students are engaged in sports sections (swimming, volleyball, basketball, Russian rounders, chess and others) and in the circles of artistic and aesthetic orientation (choreography, vocal, visual arts), along with intellectual pursuits. This makes it possible to strengthen their health and reduce the emotional burden.

The Lyceum's educational activities are carried out in close cooperation with the Innopolis University. The following directions are implemented in the framework of this cooperation:

- Methodological support and professional development, improving of Lyceum Innopolis teachers.

- The pupil involvement in the lyceum Olympiad movement and preparing Lyceum students for the Informatics Olympiad based in the Innopolis University.

- Development of Lyceum students' interest to the robotics design and preparing them to compete in robotics.

- Assisting in the preparation of in-depth Lyceum English language learners by engaging teachers of Innopolis University - native speakers for classes with Lyceum students.

- Organization of lectures for Lyceum students and meetings with Innopolis University teachers and representatives of leading IT companies and research centres in Russia and abroad.

Educational Lyceum programme and listed areas of cooperation with the Innopolis University certainly contributes to the empowerment of innovative technologies usage in education, the satisfaction of individual needs and students' development of intellectual abilities, formation of their conscious choice and the subsequent development of vocational training programs.

\section{Pre-University Additional Studying for School Students}

STEM program education in Innopolis University. To be better prepared for the workforce of the future,students need to understand and apply important concepts in Science, Technology, Engineering and Math (STEM) as well as Computer Science.

STEM programs teach students core concepts in STEM and Computer Science in programming both physical and virtual robots to creatively solve real-world problems. This learning-by-doing approach provides students with the opportunity to immediately apply the concepts they are learning through engaging projects. In effect, they are being trained as they are being taught.

Innopolis University STEM school programs employ a unique 3-tier model:

- A foundational element where core concepts in SCIENCE, TECHNOLOGY, ENGINEERING and MATH (STEM) are taught.

- A $21^{\text {st }}$ Century skills element where teamwork, communications and decision-making skills are emphasized, explored and practiced.

- A project-based learning element where application of the first two tiers is conducted in real-world projects. 
World Robot Olympiad in Russia. Innopolis University is a National Organizer of WRO in Russia (Fig. 2).

In 2014 the agreement was signed between Innopolis University and World Robot Olympiad Association Ltd. according to which Innopolis University is a national organizer of WRO in Russia for the future 5 years.

Institute of Robotics:

- Intelligent Robotic Systems Lab.

- Cognitive Robotic and Systems Lab.

\section{Conclusions}

Potential of collaboration with Innopolis University:

- Achieving the synergistic effect of coupling your experience with our expertise.

- Access to talented students and outstanding scientists.

- Involvement in the ambitious project of creation of a new growing point of innovative economy.

- Access to the state-of-the-art physical and technological infrastructure.

Innopolis University collaborates with a number of highly reputed institutions:

- Carnegie Mellon University (USA). http: //www. cmu.edu/

- School of Computing, National University of Singapore (Singapore). https://www. comp.nus.edu.sg/

- Informatics Institute, University of Amsterdam (the Netherlands). http://ivi.uva.nl/

- Chair of Software Engineering, ETH Zurich (Switzerland). http://se.inf .ethz.ch/

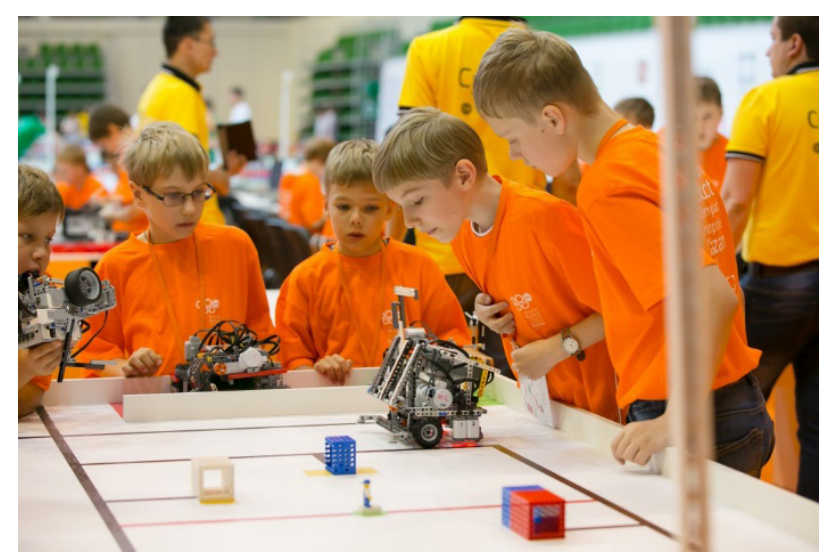

Fig. 2. WRO (World Robot Olympiad) Russia 2014, 20-22 June, Kazan: 720 participants, 373 teams, 42 regions of Russia, 2000 guests. 
- Department of Computer Science, KAIST (Republic of Korea). https://cs.kaist.ac.kr/

- Department of Computer Science and Engineering, Seoul National University (Republic of Korea). http://ee.snu.ac.kr/en

- School of Engineering, Hong Kong University of Science and Technology (Hong Kong). http: //www. seng. ust.hk/web/eng/

- School of Industrial and Information Engineering, Polytechnic University of Milan (Italy).

http://www . polimi.it/en/programmes/schools/school-of-industrial-and-information-engineering/

- Department of Computer, Control and Management Engineering, Sapienza University of Rome (Italy). http://www.dis.uniroma1.it/en

- Barcelona School of Informatics, Polytechnic University of Catalonia (Spain). http://www.fib.upc.edu/en.html

- Federal University of Minas Gerais (Brazil). https://www . ufmg.br/english/

- IT University of Copenhagen (Denmark). http://en.itu.dk/

- EURECOM (France). http://www . eurecom.fr/en

- Lappeenranta University of Technology (Finland). http://www. lut.fi/web/en/

- European Organization for Nuclear Research, CERN. http://home.cern/

\section{References}

IU (2016). Innopolis University. http: //university . innopolis .ru/en/about/

RFG (2014). The Concept of the Federal Target Program of Education Development for 2016-2020. Approved by Decree of the Russian Federation Government 29.12.2014, № 2765-p. ( In Russian). http://base. consultant. ru/cons/cgi/online. cgi?req=doc; base=LAW; $\mathrm{n}=180188$

RFP (2010). The National Educational Initiative: Our New School. Approved by Decree of the Russian Federation President 4.02.2010, number 271. (In Russian).

http: //xn--80abucjiibhv9a. xn--p1ai/\%D0\%B4\%D0\%BE\%D0\%BA\%D1\%83\%D0\%BC\%D0\%B5\%D0\%BD\%D1 $\% 82 \% \mathrm{D} 1 \% 8 \mathrm{~B} / 1450$ 


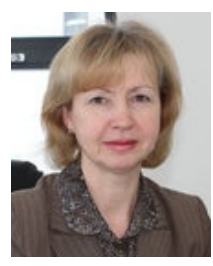

N.A. Sulimova, principal of Autonomous State General Educational Institution "Lyceum Innopolis", Honorary Worker of the general education system of Russian Federation.

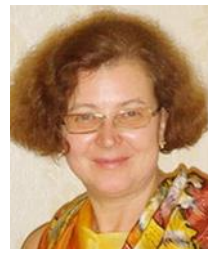

M.S. Tsvetkova, professor of the Russian Academy of Natural Sciences, $\mathrm{PhD}$ in pedagogic science, prize-winner of competition "The Teacher of Year of Moscow" (1998), main expert of state projects of school education informatization in the Ministry of Education of the Russian Federation (2001-2005), the expert of the World bank project "Informatization of Education System". Since 2002 she is a member of the Central methodical commission of the Russian Olympiad in informatics, the pedagogic coach of the Russian team on the IOI. She is the author of many papers and books in Russia on the informatization of education and methods of development of talented students. Since 2013 she is the Russian team leader. 